IRA-International Journal of Applied Sciences ISSN 2455-4499; Vol.05, Issue 01 (2016)

Institute of Research Advances

Pg. no. 6-17

http://research-advances.org/index.php/IRAJAS

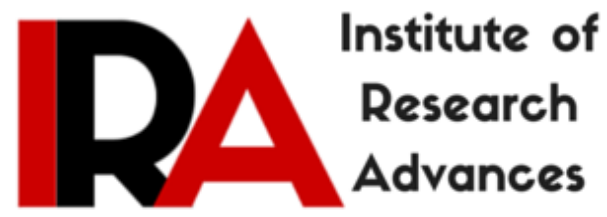

\title{
Oral Lichen Planus - A Case Report with Current Trends Review of Literature
}

\author{
${ }^{1}$ Dr. Umamaheswari G \\ Post Graduate Student, \\ Department of Oral Pathology and \\ Microbiology, \\ Indira Gandhi Institute of Dental \\ Sciences, \\ Sri Balaji Vidyapeeth University, \\ Pondicherry, India. \\ ${ }^{2}$ Dr. Suganya. $\mathbf{R}$ \\ Senior Lecturer, \\ Department of Oral Pathology and \\ Microbiology, \\ Indira Gandhi Institute of Dental \\ Sciences, \\ Sri Balaji Vidyapeeth University, \\ Pondicherry, India.
}

\author{
${ }^{3}$ Dr. Sivaramakrishnan. $M$ \\ Senior Lecturer, \\ Department of Oral Pathology and \\ Microbiology, \\ Indira Gandhi Institute of Dental \\ Sciences, \\ Sri Balaji Vidyapeeth University, \\ Pondicherry, India.
${ }^{4}$ Dr. Vidyalakshmi. S
Senior Lecturer,
Department of Oral Pathology and
Microbiology,
Indira Gandhi Institute of Dental
Sciences,
Sri Balaji Vidyapeeth University,
Pondicherry, India.

Type of Review: Peer Reviewed.

DOI: http://dx.doi.org/10.21013/jas.v5.n1.p2

\section{How to cite this paper:}

G, Umamaheswari, R, Suganya, M, Sivaramakrishnan, \& S, Vidyalakshmi (2016).

Oral Lichen Planus - A Case Report with Current Trends Review of Literature. IRA-

International Journal of Applied Sciences (ISSN 2455-4499), 5(1), 6-17.

doi:http://dx.doi.org/10.21013/jas.v5.n1.p2

(C) Institute of Research Advances

(oc) EY-No This work is licensed under a Creative Commons Attribution-Non Commercial 4.0 International License subject to proper citation to the publication source of the work.

Disclaimer: The scholarly papers as reviewed and published by the Institute of Research Advances (IRA) are the views and opinions of their respective authors and are not the views or opinions of the IRA. The IRA disclaims of any harm or loss caused due to the published content to any party. 


\section{ABSTRACT}

Lichen planus (LP) is an autoimmune chronic mucocutaneous dermatosis that commonly affects skin, mucous membrane, hair follicles \& nails. Skin lesions present as recurrent violaceous, keratotic pruritic patches whereas oral lichen planus presents with various pattern. Oral lesions of LP is approximately of $1-2 \%$ of general population while 10-20\% of patients demonstrate oral as well as cutaneous lesions. Females are most commonly affected with age group ranging from 40-70 years and showing prevalence rates varying from $0.5 \%$ to $2.6 \%$ of the world population. The malignant transformation potential of LP into oral squamous cell carcinoma (OSCC) is 0.3-3\%. Epithelial dysplasia is considered to be a risk factor for malignant transformation into OSCC. The objective of this paper is to report a case of oral lichen planus showing features of dysplasia in a young male patient.

Key words: Oral Lichen planus, Mucocutaneous lesion, Autoimmunity

\section{Introduction:}

Oral mucous membrane is affected by variety of mucocutaneous diseases. Autoimmune mediated, infectious, neoplastic, hematologic, reactive, nutritional and idiopathic causes may be the etiological factors involved. Approximately, 50\% of oral mucosal diseases are localized to gingiva causing desquamative gingivitis, although other intraoral and extraoral sites may be involved and most of these disease have dermatologic genesis. [1]

Lichen planus (LP) is chronic mucocutaneous disease of dermatologic genesis, that affects the skin, oral and other mucosae such as nasal, ocular, genital mucosa and may also affect other parts of the body such as hair follicles, nails, larynx and eyes. [2] It was first described and named by Erasmus Wilson in 1869. [3] The word 'lichens' means primitive plants composed of symbiotic algae and fungi and the term 'planus' is from Latin which means flat. [4] WHO defines OLP as the risk of malignancy being present in a lesion or condition either at time of initial diagnosis or at a future date and included the oral lesions of lichen planus in its classification as a potentially malignant disorder. [5]Oral manifestation of these disease is approximately of $2 \%$ of general population [6] while $10-20 \%$ of patients demonstrate oral as well as cutaneous lesions. [7]

Skin lesion typically present as small (2mm) flat-topped, pruritic, shiny, polygonal, violaceous papules that may coalesce into plaques, which can increase in size to as much as $3 \mathrm{~cm}$. The following clinical presentations of LP of skin have been observed: annular, linear, atrophic, bullous, hypertrophic, ulcerated and pigmented. [4] Cutaneous LP is typically considered to have an acute progression and also a self-limiting condition (except for the hypertrophic form), usually resolves within 6-12 months. [8]

The lesion when it affects the oral mucosa is termed as oral lichen planus (OLP) [4]recognized as a non-infectious chronic inflammatory condition that involves the oral mucous stratified squamous epithelium and the underlying lamina propria [8], which may or may not be accompanied by cutaneous lesions. [7] Intraoral features of these lesions presents with the various patterns like reticular, papular, plaque-like, atrophic, erosive or bullous lesions with predominance of reticular pattern. [9] The prevalence rates of OLP vary from $0.5 \%$ to $2.6 \%$ of the world population with maximum prevalence among women above the age of 40years. [4,10].The causes of initiation and progression of OLP were found to be an unknown. Although the exact etiopathogenesis of OLP is uncertain, dysregulated T cellmediated disorder to exogenous triggers versus a dysregulated response to autologous keratinocyte antigens (autoimmune) can exist to explain its major role. [8] World health organization (WHO) considers it to be a potentially malignant disorder [4] and the actual malignant transformation potential has been put between $0.3 \%-3 \%$.[11] 


\section{Case Report:}

A 27-years old male patient reported to the out patient department of Indira Gandhi Institute of Dental Sciences, Puducherry with the chief complaint of burning sensation in the mouth for the past 1 month. Initially the patient noticed white areas on cheeks bilaterally for past 7 months followed by burning sensation. Drug history was not elucited and patient was also not aware of same lesion in sites other than oral cavity. Intra oral examination revealed a linear white lace like pattern of size $2 \times 2 \mathrm{~cm}$ present in the left buccal mucosa with white striations [Fig:1a,1b]. Similar lesions were also found other sites of oral cavity. No ulcerations or erythematous areas seen. On palpation, it is a non-scrapable and non-tender lesion. Clinically it was diagnosed as reticular lichen planus. Histopathological examination revealed layers of hyperplastic stratified squamous epithelium with parakeratosis. Epithelium exhibited acanthosis and basilar degeneration. Some areas shows the features of pleomorphism, hyperchromatism which extended to spinous layer with large bulbous rete ridges. In the areas of dysplastic epithelium and bulbous rete ridges, there is a sub-epithelial infiltration of band of chronic inflammatory cells predominantly of lymphocytes [Fig:2a,2b].The final diagnosis was Lichen Planus, with areas of dysplasia.

\section{Discussion:}

Lichen planus (LP) is a chronic autoimmune disease with an unknown etiology that is marked by the invasion of lymphocytic infiltrate within the epithelial tissue inducing epithelial cell apoptosis and chronic inflammation at the juxtaepithelial region. [12] Oral mucosal lesions follow a more chronic course and follows a cyclic pattern of exacerbation and remission. It has been observed that the oral lesions may persist upto 25 years [4] and precipitate during the periods of stress.[13] In the present case it is reported in a 27 year old male patient.

\section{Etiopathogenesis:}

Certain etiological factors that can predispose OLP have been proposed, mainly

1) Stress: Stress is thought to assume a part in the pathogenesis of OLP, on the grounds that anxiety and depression are apparently more common in OLP patients. These immune response changes are predominantly mediated via neuro-endocrine mediators from the hypothalamic-pituitary-adrenal axis and the sympathetic-adrenal axis The ramifications of these studies is that, like other provocative states of different causes, anxiety will probably play an optional, as opposed to an essential, part in OLP pathogenesis. [8]

2) Autoimmune response to epithelial antigens vs. a dysregulated response to external antigens: Immune system reaction to epithelial self-antigens remains a probability. An immunologic marvel termed epitope spreading has been an essential pathogenic mechanism for the initiation and/or progression of lesion with autoimmune etiology. Epitope spreading could be characterized as a specific autoreactive lymphocyte (T-or B cell) reaction to endogenous epitopes, which are distinct from and non-cross-reactive with the disease-inducing epitopes, on the same or different proteins auxiliary to the release of such a self-protein during an autoimmunity response.[1]

3) Viral Infections: Various potential relationship between particular viral contaminations and OLP have been researched, including CMV, HSV-1, HHV-6, EBV, HBV and HPV, without uncovering huge correlations. Currently, there is persuading proof that at any rate in some geographic areas, OLP is connected with hepatitis $\mathrm{C}$ infection (HCV) disease. [8]

Crispian Scully et al in 2008 [14]: Pathogenesis of oral LP. (Fig. 3)

Sugerman et al [15] : (Fig.4) 
The lichen planus antigen as of now is still unknown, and considered to be a self-peptide, thus classifying lichen planus as an autoimmune disease. It has been identified that heat-shock protein (HSP) expression is up-regulated by OLP lesional keratinocytes. Such an immune response has been supported by the fact that patients with oral lichen planus show depressed immunological suppressor activity.

Andreasen in 1968 clinically divided OLP into six types , [Table 1][4,16]

The histopathology of OLP was first described by Dubreuill in 1906, and it was revised by Shklar in 1972, who described three characteristic features: (1) overlying keratinization; (2) liquefaction degeneration of the basal cell layer; and (3) a dense sub-epithelial band of lymphocytes.[17] The features of lichen planus include hyperkeratosis, epithelial acanthosis, basal cell layer vacuolation, saw-tooth rete ridges, and a dense band-like sub-epithelial infiltrate of T-lymphocytes. Cytoid, Hyaline, Civatte bodies are usually seen at the epithelial-connective tissue interface and they represent necrotic keratinocytes.[11,18] Degeneration of basal keratinocytes and disruption of anchoring elements such as hemidesmosomes, filaments, fibrils weakens the epithelial-connective tissue interface resulting in histological cleft termed as Max- Joseph spaces and it is clinically identified as blister on the oral mucosa in case of bullous lichen planus [11]. Present case showing the features of hyperkeratosis, basal cell degeneration and dense chronic inflammatory cell infiltrate at the sub epithelial region, along with these dysplasia features were also noticed and gives the diagnosis lichen planus with dysplasia.

Various systemic disorders have been associated with OLP, for example, diabetes, hepatitis-C $(\mathrm{HCV})$, and hypertension. This triad of OLP, diabetes mellitus and hypertension has been termed "Grinspan's disorder" in which the white lesions are because of the medications utilized for the previously stated systemic diseases. Both cutaneous LP and OLP are found in association with chronic liver illness secondary to HCV infection. Lichen planus may likewise take up with other immune mediated diseases including alopecia areata, dermatomyositis, lichen sclerosis atrophicus, morphea, myasthenia gravis, essential biliary cirrhosis, ulcerative colitis and vitiligo.[4]

Diagnosis of OLP is based on combined clinical and histopathological investigation. The widely used definition for the diagnosis of OLP was the criteria introduced by World Health Organization (WHO) in 1978 give in [table-2] [19] Modified World Health Organization diagnostic criteria of OLP and OLL (2003) [table-3] [17]

Differential diagnosis include, leukoplakia, lupus erythematosus and graft versus host disease (GVHD), lichenoid eruptions associated with medications, lichenoid lesions associated with contact with restorative materials. [20]

Management of OLP patients, local exacerbating factors need to be removed. Scaling and self oral cleanliness support are required. Teeth associated with oral lesions should be examined and sharp cusps or edges reduced. [21]Drugs including corticosteroids, retinoids and cyclosporine have been attempted and observed. Cryosurgery and carbon dioxide laser removal were thought to be other treatment modalities of OLP. Surgical treatment is more relevant to the plaque like injuries, in light of the fact that the influenced surface epithelium can be evacuated effectively and not appropriate for erosive and atrophic type as that the surface epithelium is eroded. However, excision should not be a primary method of treatment as it is an inflammatory condition that can recur.[4]

Conclusion: OLP has been moved from being regarded as an innocuous benign condition to being defined as a potentially malignant disorder by the world health organization (2005). It's etiology is primarily considered to be a T-cell mediated autoimmune disorder in the basal keratinocytes are attacked by the lymphocytes. Present case was clinically \& histopathology diagnosed as lichen planus showing a feature of moderate dysplasia. Since OLP is considered to be a potentially malignant disorder there is a 
need for more caution about dysplasia. Therefore regular and periodic checkups are needed to detect malignant transformation at early stages.

\section{References}

1. Sangeetha S, Victor DJ. The molecular aspects of oral mucocutaneous diseases: A review. Int.J.Genet.Mol.Biol 2011; 3(10):141-148.

2. Elder DE, Elenitsas R; Johnson B L, Murphy GF. Lever's Histopathology of the Skin, $9^{\text {th }}$ ed, Lippincott Williams \& Wilkins. 2005

3. Wilson E .On lichen planus. J Cutan Med Dis Skin 1869;3:117-132.

4. Chitturi RT, Devy AS, Nirmal RM, Sunil PM. JBR Journal of Interdisciplinary Oral Lichen Planus : A Review of Etiopathogenesis , Clinical , Histological and Treatment Aspects.2014; 2(5).

5.George A, Sreenivasan BS, Sunil S, Varghese SS, Thomas J Potentially malignant disorders of oral cavity. Oral \& Maxillofacial Pathology Journal 2011; 2: 95-100

6. Axell T, Rundquist L. Oral lichen planus - demographic study. Community Dent Oral Epidemiol 1987; 15:52-56.

7. Conklin RJ, Blasberg B. Oral lichen planus. Dermatol Clin 1987;5:663-673.

8. Kurago ZB. SC. Oral Surg Oral Med Oral Pathol Oral Radiol [Internet]. Elsevier Ltd; 2016; Available from: http://dx.doi.org/10.1016/j.o0oo.2016.03.011

9. Thorn JJ, Holstrup P, Rindum H, Pindborg JJ. Course of various clinical forms of oral lichen planus. A prospective follow-upstudy of 611 patients. J Oral Pathol Med 1988;17:213-318.

10. Simpson HE. The age and sex incidence and anatomical distribution of oral leukoplakia and lichen planus. Br J Dermatol 1957; 69:178-180

11. Rajendran A, Sivapathasundharam B. Shafer's textbook of oral pathology. In: Rajendran, Diseases of the skin. $6^{\text {th }}$ ed. Noida, New Delhi: Elsevier 2009. p.(799-803)

12. Scully C, Carrozzo M. Oral mucosal disease: Lichen planus. Br J Oral Maxillofac Surg 2008; 46:1521.

13. Sugerman PB, Savage NW Oral lichen planus: causes, diagnosis and management. Aust Dent J 2002; 47: 290-297.

14. Crispian Scully, Marco Carrozzo. Oral mucosal disease:Lichen planus. British Journal of Oral and Maxillofacial Surgery 2008; 46:15-21.

15. P.B. Sugerman, N.W. Savage, L.J. Walsh, Z.Z. Zhao, X.J. Zhou, A. Khan, G.J. Seymour, M. Bigby. The pathogenesis of oral lichen planus. CROBM 2002;13:350.

16. Andreasen JO. Oral lichen planus. 1. A clinical evaluation of 115 cases. Oral Surg Oral Med Oral Pathol 1968; 25: 31-42

17. Shirasuna K. Oral lichen planus : Malignant potential and diagnosis. Japanese Stomatological Society; 2014; 11:1-7

18. Lodi G, Scully C, Carrozzo M, Griffiths M, Sugerman PB, et al. Current controversies in oral lichen planus: Report of an international consensus meeting. Part I. Viral infections and etiopathogenesis. Oral Surg Oral Med Oral Pathol Oral Radiol Endod 2005; 100: 4051

19. Rad M, Hashemipoor MA, Mojtahedi A, Zarei MR, Chamani G, et al. Correlation between clinical and histopathologic diagnoses of oral lichen planus based on modified WHO diagnostic criteria. Oral Surg Oral Med Oral Pathol Oral Radiol Endod 2009; 107: 796-800.

20. Ismail SB, Kumar SK, Zain RB. Oral lichen planus and lichenoid reactions: etiopathogenesis, diagnosis, management and malignant transformation. J Oral Sci 2007; 49:89-106

21. Sugerman PB, Savage NW, Zhou X, Walsh LJ, Bigby M Oral lichen planus. Clin Dermatol 2000; 18: 533-539. 
(Figures \& Tables)

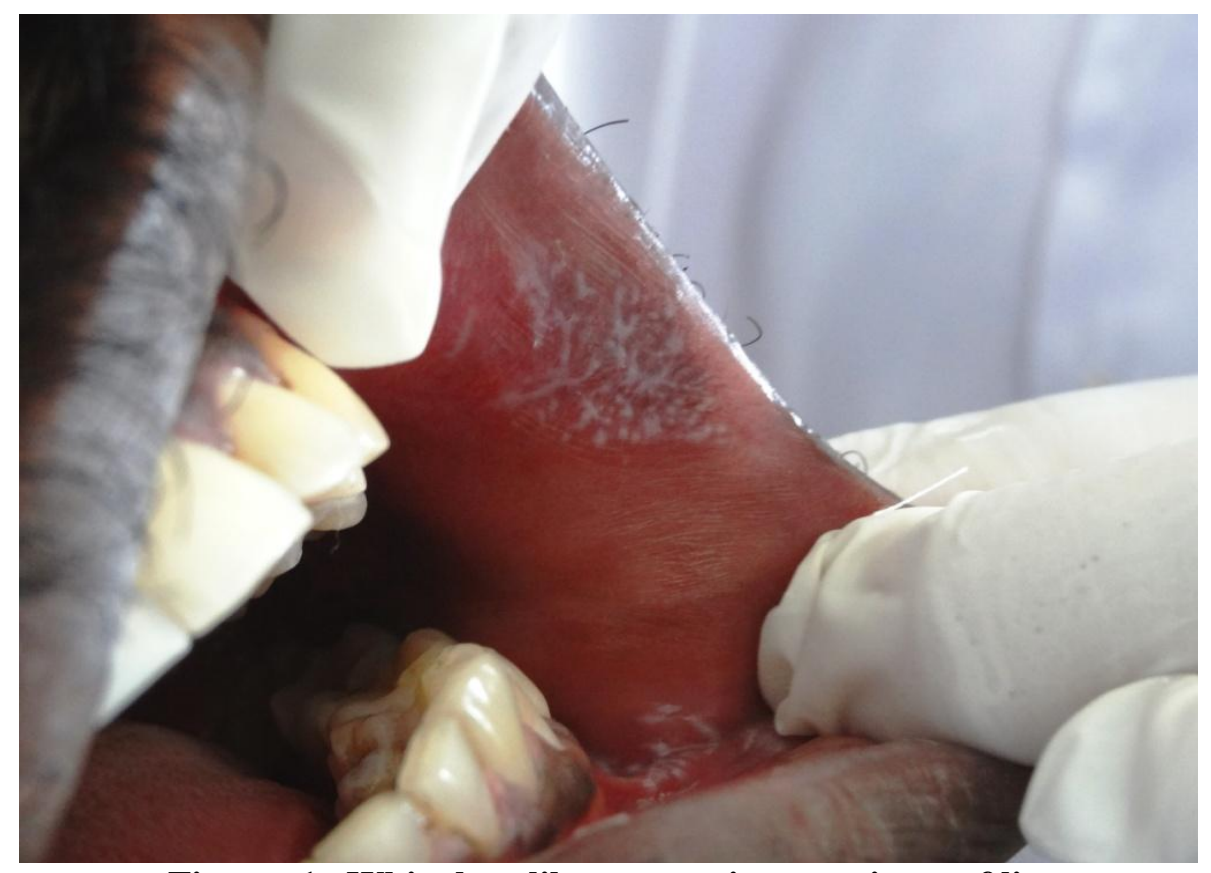

Figure: 1a White lace like pattern in commisure of lip

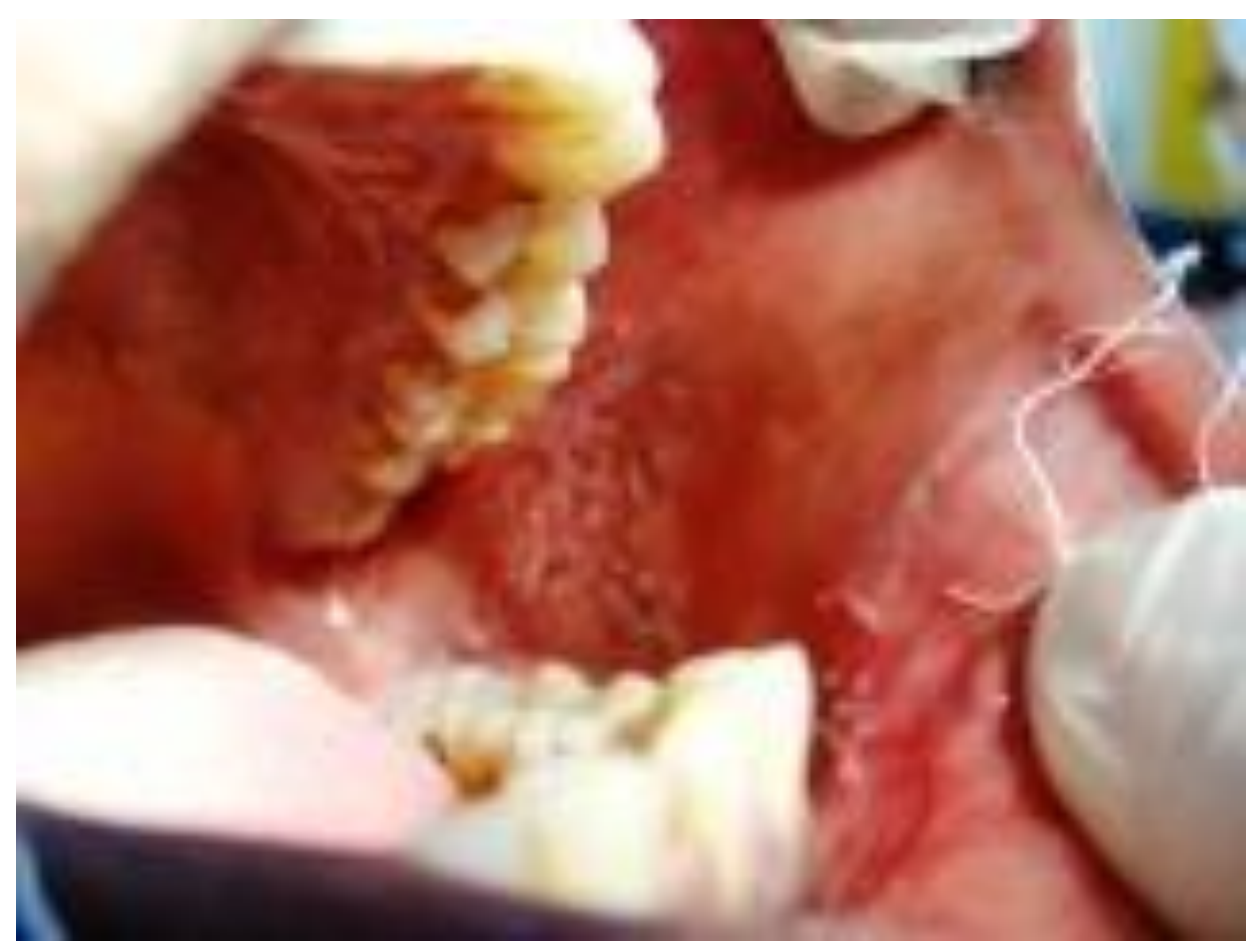

Figure: 1b White lace like pattern in the left buccal mucosa 


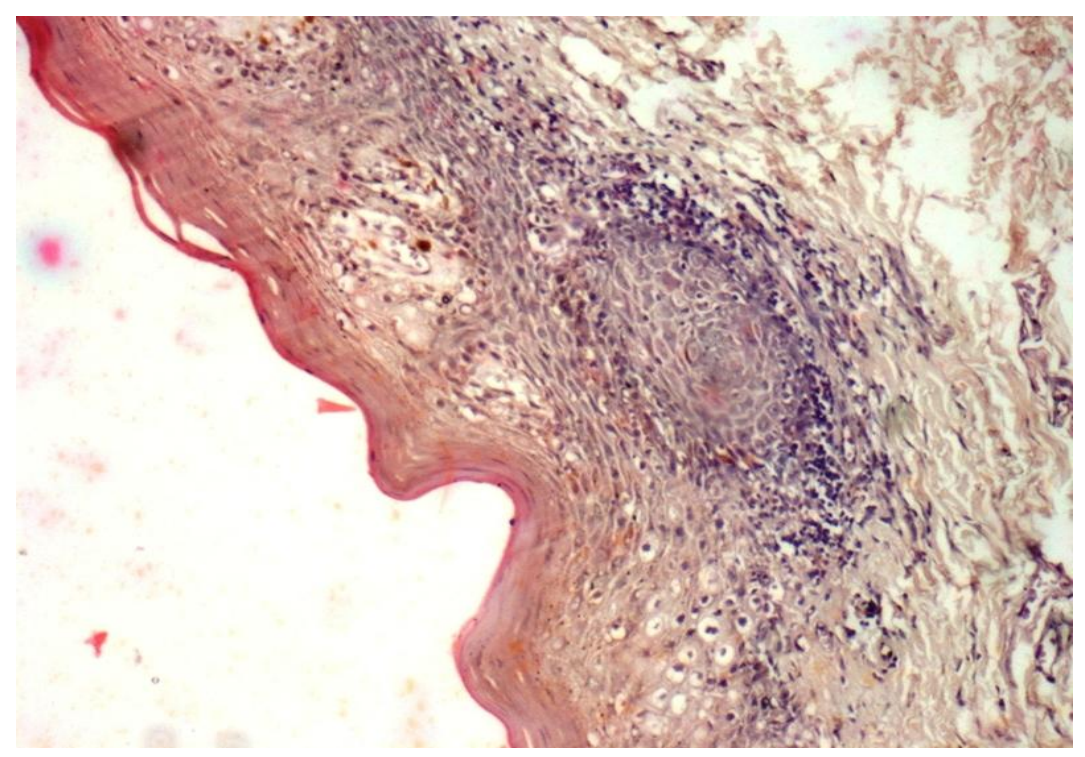

Figure 2a: Photomicrograph showing Keratinized Epithelium with basal cell degeneration and features of dysplasia

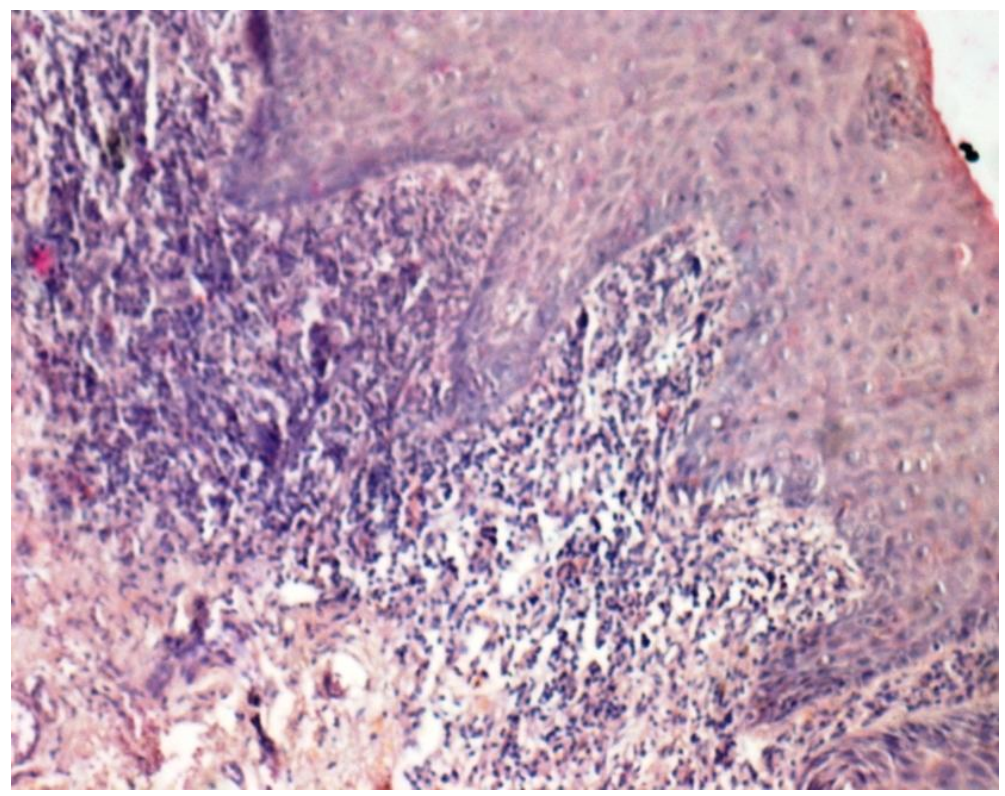

Figure 2b: Photomicrograph showing Band of inflammatory cell infilterate in sub epithelial zone 
Fig. 3: Pathogenesis of oral LP - Crispian Scully et al

Type 1 Helper T-cells - increased production (Genetically induced)

Release cytokines

(based on genetic polymorphism of cytokines)

IFN- $\gamma$ associated

TNF- $\alpha$ associated

(only oral mucosa)

(oral mucosa and skin)

$\downarrow$

Oral epithelium express chemokines

1) Intercellular adhesion molecule (ICAM, VCAM)

2) Epithelial basement membrane, Extracellular matrix proteins (Collagen IV, VII, Laminin, Integrin, CXCR3, CCR5)

3) $\mathrm{TNF}-\alpha$

4) $\mathrm{IL}-1, \mathrm{IL}-8, \mathrm{IL}-10, \mathrm{IL}-12$

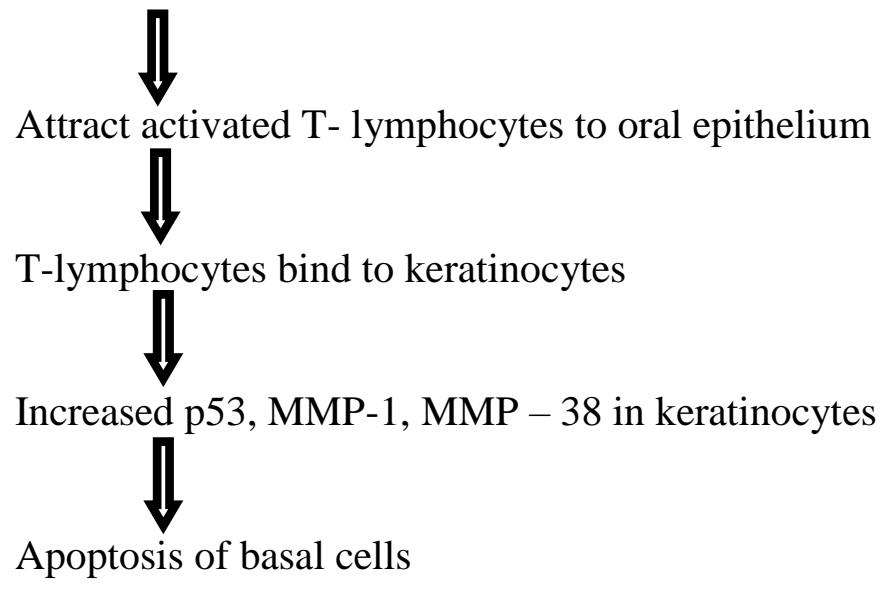

Activation of NF- $\mathrm{k} B \quad$ inhibition of TGF
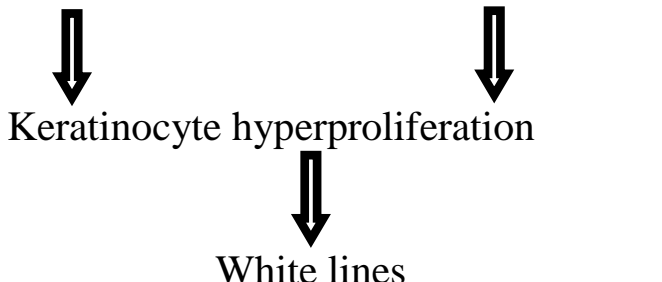
Fig. 4: Pathogenesis of oral LP - Sugerman et al

Stress to keratinocytes

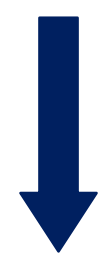

Systemic drugs

Contact allergens

Minor trauma

Bacterial and viral infections

Dysregulated expression of Heat Shock Proteins (HSP) by keratinocyte

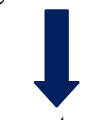

HSP as auto-antigen<smiles>[CH-]1CCC1</smiles>

CD 8+ T cells recognize HSP on basal keratinocytes

(1. "Chance encounter" on routine surveillance or

2. "Directed migration" by keratinocyte derived chemokines)

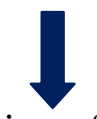

Activation of T cells

$\checkmark$

Keratinocyte apoptosis

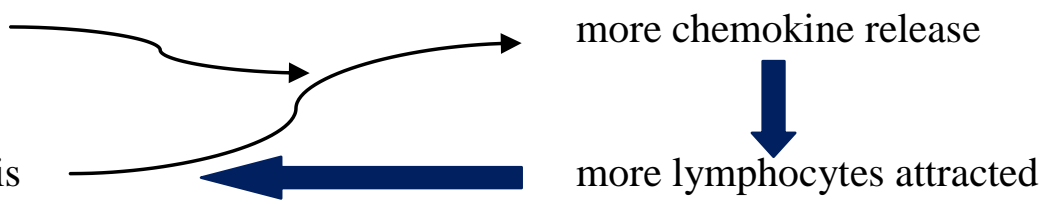

(i) TNF- $\alpha$ binding to TNF- $\alpha$ receptor 1 (TNF R1) on the keratinocyte surface which is secreted by the T-cells,

(ii) CD95L (Fas ligand) present on the T-cell surface binding to CD95 (Fas) on the keratinocyte surface, or

(iii) T-cell-secreted Granzyme B enter the keratinocyte through membrane pores induced by perforin. All of these mechanisms may result in activating the keratinocyte into the caspase cascade, causing keratinocyte apoptosis. ${ }^{(15)}$ 
Table -1 Various clinical types of lichen planus, clinical presentation \& common sites [4]

\begin{tabular}{|c|c|c|}
\hline Clinical Type & Clinical presentation & Common site \\
\hline $\begin{array}{l}\text { Reticular Type } \\
\text { (resolve by } 41 \% \text { ) }\end{array}$ & $\begin{array}{l}\text { a series of fine, radiant, white striae } \\
\text { known as 'Wickham striae', which may } \\
\text { be surrounded by a discrete } \\
\text { erythematous border }\end{array}$ & $\begin{array}{l}\text { Buccal mucosa,lateral border of } \\
\text { tongue, gingiva }\end{array}$ \\
\hline Papular & $\begin{array}{l}\text { As small white pinpoint papules about } \\
0.5 \mathrm{~mm} \text { in size }\end{array}$ & \\
\hline $\begin{array}{l}\text { Plaque } \\
\text { (Resolve by 7\%) }\end{array}$ & $\begin{array}{l}\text { Homogenous white patches, ranges from } \\
\text { a slightly elevated, smooth patch to a } \\
\text { slightly irregular form and may also be } \\
\text { multifocal }\end{array}$ & $\begin{array}{l}\text { Dorsum of the tongue and the } \\
\text { buccal mucosa }\end{array}$ \\
\hline $\begin{array}{l}\text { Atrophic } \\
\text { (Resolve by } 12 \% \text { ) }\end{array}$ & $\begin{array}{l}\text { A diffuse, red and there are usually white } \\
\text { striae around the lesion. Such striae that } \\
\text { radiate peripherally and are usually } \\
\text { evident at the margins of the atrophic } \\
\text { zones of the lesion }\end{array}$ & $\begin{array}{l}\text { Attached gingiva is often involved } \\
\text { and the condition is commonly } \\
\text { referred to as 'chronic } \\
\text { desquamative gingivitis'. Lingual } \\
\text { gingiva is usually less severely } \\
\text { involved. }\end{array}$ \\
\hline Bullous & $\begin{array}{l}\text { Small bullae or vesicles of size ranges } \\
\text { from a few millimeters to several } \\
\text { centimeters in diameter, that tend to } \\
\text { rupture easily and leave as painful ulcers }\end{array}$ & $\begin{array}{l}\text { buccal mucosa, particularly in the } \\
\text { posteroinferior areas adjacent to } \\
\text { the second and third molar teeth, } \\
\text { lateral margins of the tongue and } \\
\text { rarely on the gingiva or inner } \\
\text { aspect of the lips }\end{array}$ \\
\hline Erosive & $\begin{array}{l}\text { Irregular in shape and covered with a } \\
\text { fibrinous plaque or pseudomembrane } \\
\text { where there is an erosion. }\end{array}$ & \\
\hline
\end{tabular}


Table 2: World Health Organization diagnostic criteria (1978) of oral lichen planus (OLP) [23]

\begin{tabular}{|c|c|}
\hline CLINICAL CRITERIA & HISTOPATHOLOGIC CRITERIA \\
\hline $\begin{array}{l}\text { - Presence of white papule, reticular, annular, } \\
\text { plaque-type lesions, gray-white lines radiating from } \\
\text { the papules. } \\
\text { - Presence of a lace-like network of slightly raised } \\
\text { gray-white lines (reticular pattern). } \\
\text { - Presence of atrophic lesions with or without } \\
\text { erosion, and also in the form of bullae. }\end{array}$ & $\begin{array}{l}\text { - Presence of thickened ortho or parakeratinized } \\
\text { layer in sites with normally keratinized mucosa, } \\
\text { and if site normally is nonkeratinized this layer } \\
\text { may be very thin. } \\
\text { - Presence of civatte bodies in basal layer, } \\
\text { epithelium and superficial part of the connective } \\
\text { tissue. } \\
\text { - Presence of a well-defined band like zone of } \\
\text { cellular infiltration that is confined to the } \\
\text { superficial part of the connective tissue, consisting } \\
\text { mainly of lymphocytes. } \\
\text { - Signs of 'liquefaction degeneration' in the basal } \\
\text { cell layer }\end{array}$ \\
\hline
\end{tabular}


Table 3: Modified World Health Organization diagnostic criteria of OLP and OLL (Oral lichenoid lesions) (2003). [22]

\begin{tabular}{|c|c|c|}
\hline Clinical criteria & Histopathologic criteria & Final diagnosis OLP or OLL \\
\hline $\begin{array}{l}\text { - Presence of bilateral, } \\
\text { more or less } \\
\text { symmetrical lesions } \\
\text { Presence of a lace-like } \\
\text { network of slightly } \\
\text { raised gray-white lines } \\
\text { (reticular pattern) } \\
\text { - Erosive, atrophic, } \\
\text { bullous, and plaque-type } \\
\text { lesions are accepted } \\
\text { only as a } \\
\text { subtype in the presence of } \\
\text { reticular lesions elsewhere } \\
\text { in the oral mucosa } \\
\text { In all other lesions that resemble } \\
\text { OLP but do not complete the } \\
\text { aforementioned } \\
\text { criteria, the term "clinically } \\
\text { compatible with" should be used }\end{array}$ & 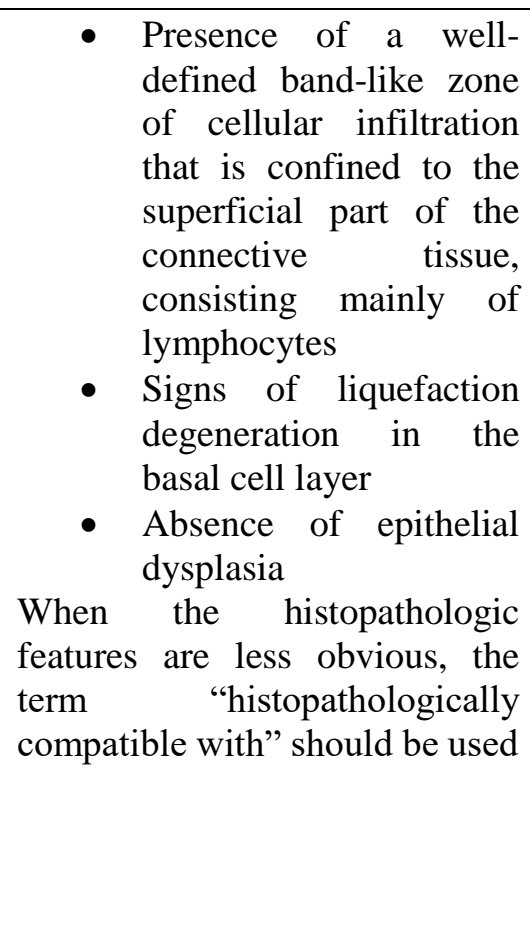 & $\begin{array}{l}\text { To achieve a final diagnosis, } \\
\text { clinical as well as histopathologic } \\
\text { criteria should } \\
\text { be included } \\
\text { OLP: A diagnosis of OLP requires } \\
\text { fulfillment of both clinical and } \\
\text { histopathologic criteria } \\
\text { OLL: The term OLL will be used } \\
\text { under the following conditions: } \\
\text { 1. Clinically typical of OLP but } \\
\text { histopathologically } \\
\text { compatible with } \\
\text { OLP } \\
\text { 2. Histopathologically typical of } \\
\text { OLP but clinically only compatible } \\
\text { with } \\
\text { OLP } \\
\text { 3. Clinically compatible with OLP } \\
\text { and histopathologically compatible } \\
\text { with } \\
\text { OLP }\end{array}$ \\
\hline
\end{tabular}

